\title{
AUTOMATION OF RIDE ORDERS FOR PASSENGER VEHICLES
}

\author{
Rajko M. Terzića ${ }^{a}$ Zoran S. Eremija ${ }^{b}$, Dušan R. Terzićc \\ ${ }^{a}$ Institute of Public Health, Belgrade, Republic of Serbia, \\ e-mail: rajko.terzic@gmail.com \\ ORCID iD: Dhttp://orcid.org/0000-0003-0772-8291, \\ ${ }^{\mathrm{b}}$ Dizis, Belgrade, Republic of Serbia, \\ e-mail: zoran.eremija@gmail.com, \\ ORCID iD: (1)http://orcid.org/0000-0002-6268-6111, \\ ${ }^{\mathrm{C}}$ University in Belgrade, Faculty of Organizational Sciences, Belgrade, \\ Republic of Serbia \\ e-mail: dusan.terzic@sbb.rs \\ ORCID iD: (1)http://orcid.org/0000-0002-5882-50275027
}

DOI: $10.5937 /$ vojtehg64-10228

\begin{abstract}
FIELD: computer science, information technology, industrial software ARTICLE TYPE: Original Scientific Paper ARTICLE LANGUAGE: English
\end{abstract}

\begin{abstract}
:
Effective functioning of organizations depends on the quality of management of interconnected and interdependent business processes. The key problem in the projects implementation is associated with ignorance of business processes of a business itself. The paper provides an approach for modeling business processes through a selection of tried and tested methods and models for coping with the complexity of systems. Business high-level features are decomposed into smaller functional units, resulting in a hierarchical structure of business functions of different granularity. At the bottom of the functional decomposition hierarchy, there are so-called primitive functions which are in fact managing processes. The specifications of the interactions between the systems participants are use case diagrams. The specification of business processes has been realized through BPMN diagrams (choreographies and collaboration diagrams). An automated solution improves the quality of operations and coordinates all participants in this business system. In this paper, the business analysis method has been presented as well as the results of the design of the segment called "a ride order for passenger vehicles" and the business processes closely associated with it.
\end{abstract}

Key words: company car, ride order, vehicle, BPMN, UMM, BPM, business process management systems, business process.

\section{Introduction}

The task of a business analysis is to define a quality method to recognize business needs, to define requirements and design solutions to meet the set requirements necessary to solve business needs. 
A key problem in all implementation projects of any solutions for any organization is associated with the ignorance of business processes of the organization itself (Aničin, Pantović, 2014). This ignorance does not only concern the implementer's team headed by the project manager, but it is also related to employees who need to instruct the implementer's team how the business process functions and what their real needs are (Aničin, Pantović, 2014).

Existing software solutions in this area are mostly realized on outdated software platforms, without a necessary analysis and applying the methodology of information systems. Also, most of the existing solutions do not possess software documentation, making it difficult to maintain them.

The main goal of this paper is to present a method of business analysis and the results of applying the methodology of the implementation tool Access / SQL server. It elaborates in particu ar the design results in the segment of ride orders for passenger vehicles and closely related business processes.

The paper provides an approach for modeling business processes through a selection of tried and tested methods and models for dealing with the complexity of the system.

In order to obtain a holistic view of the problem of managing interdependent business processes in a complex system, let us first explain the systems for managing business processes (Business Process Management - BPM). Business Process Management aims to improve operational business processes, possibly without the use of new technologies. Below are the definitions of modeling business processes, followed by an approach for modeling business processes. This paper presents a choice of methods and models for dealing with the complexity of the system. The application of the proposed methods and models is illustrated by a decomposition of business processes and a detailed specification of the business process of the ride order for passenger vehicles. The next chapter provides the specification of the business process management of the ride order through BPMN (Business Process Model and Notation) diagrams.

The following chapter lists the results for the system design VozIS screen forms application. The final chapter gives the conclusion that outlines the main contribution of this work and plans for future work.

\section{Methodology}

BPM is a system and a platform for connecting architecture organization, models of business processes, systems management workflow and information infrastructure to support execution of business processes. 
A modern BPM system allows users to model the analysis and simulation processes, transform models into the program code, integrate with business applications, perform process control and monitoring workflows, optimize business processes, increase customer satisfaction, reduce inefficiencies, and analyze the performance of business processes after performing (Weske, 2007).

BPM must be deeply embedded in the organizational structure and it requires a professional and efficient approach to the management process as well as the involvement of all relevant target groups.

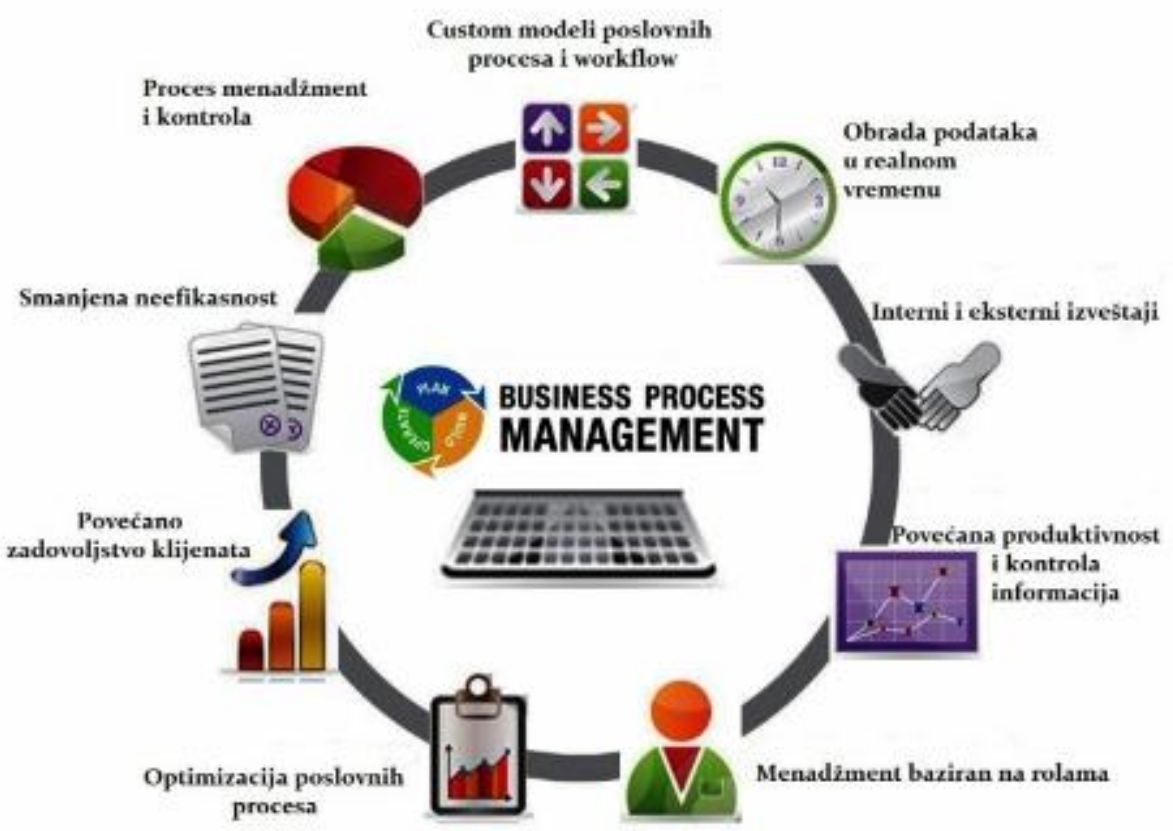

Figure 1 - Business Process Management

Puc. 1 - Управление бизнес-процессами

Slika 1 - Upravljanje poslovnim procesima

It can be seen (Figure 1) that business process management results in real-time processing, generating internal and external reports as well as in realized increased productivity and information control. Management is based on the management of roles, implemented process optimization, reducing inefficiency which leads to increased customer satisfaction.

Models are simplified real-world performances, such as models of airplanes, building plans, and database schemas. 
Models are presented in a language (language modeling) which can be a textual notation (models in the text format) and a graphic notation (models in the form of diagrams). Modeling business processes means a consistent application of graphic methods and appropriate software tools to show the reliability of business processes, but also a concrete way of their performance (Tumbas, 2006).

Business functions of higher levels can be decomposed into smaller functional units, resulting in a hierarchical structure of business functions of different granularity. At the bottom of the functional decomposition hierarchy there are so-called "primitive functions" (Lazarevic et al., 2006), which are in factexecutive processes. The process of breaking up a large fraction of functions into fine (smaller) granularity is traditionally called functional decomposition.

This paper uses the UN / CEFACT (United Nations Centre for Trade Facilitation and Electronic Business) Modeling Methodology (UMM), which is normally used in modeling business processes in e-business.

The UML package is a general mechanism for grouping any elements in the group, and, through it, for performing a decomposition of functional domains and complex processes. It has various levels of decomposition for specifically defined, specific stereotypes of business processes. The entire model is presented as package $<<$ Business Domain $>>$ (still in operation $<<b$ Domain $>>$, which is an aggregation of all sub-processes. $<<b$ Domain $>>$ is decomposed so that it can contain one or more types of complex sub-processes $<<$ Business Area $>>(<<b$ Area $>>$ ) and $<<$ process Area $>>$, or a primitive type process $<<$ Business Process $>>(<<b$ Process UC $>>)$. One process stereotype $<<b$ Area $>>$ can be decomposed to one or more complex processes stereotypes $<<$ process Area $>>$ or a primitive process stereotype $<<$ b Process UC $>>$ (Lazarević, et al., 2006).

A primitive business process can be presented through a Unified Modeling Language (UML) diagram of a use case to define the specification of the interactions between the system actors (participants), together with a description of the system actions in this interaction.

The methods and models are applied to illustrate the decomposition of business processes of organization, with a detailed specification of the business process management system for a vehicle management system.

The process is any activity or group of activities that takes an input, adds value to it and provides an output to any internal or external customers. Business processes use organizational resources to accomplish planned results (Harrington's, 1991). There are different types of business processes: (Tumbas, 2006)

- Operational processes - production, purchase, sale,

- Support processes - maintenance, accounting, IT support,

- Control processes - planning, control. 


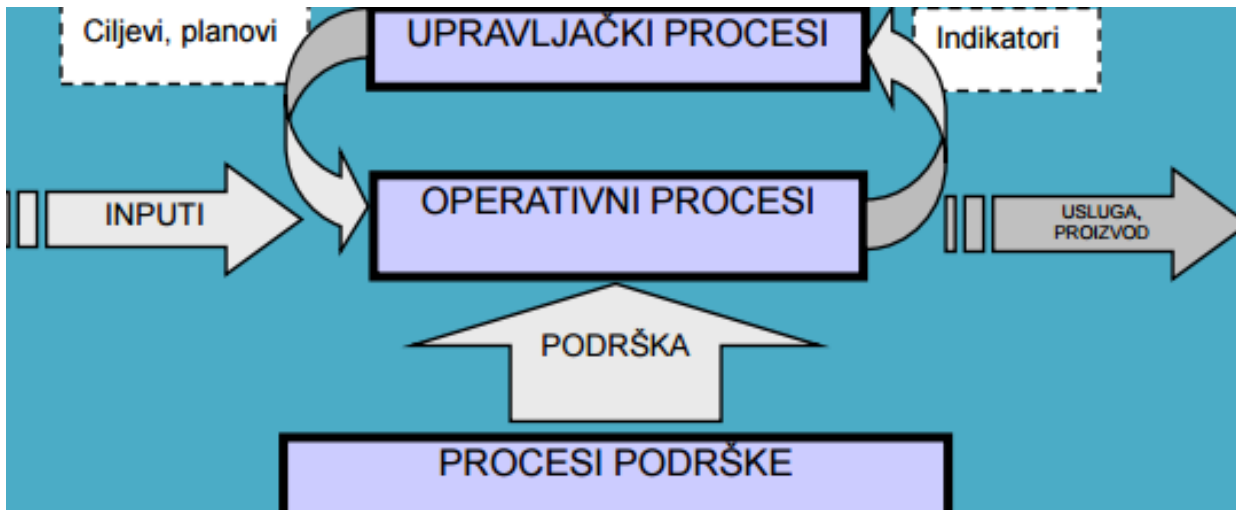

Figure 2 - Different types of business processes Puc. 2 - Различные типы бизнес-процессов Slika 2 - Različite vrste poslovnih procesa

Business processes are the "heart" of an organization and the entire business of an organizational system (e. $g$ the organization) is done through business processes.

The model shown represents the current state of the process, which can be improved in future versions. The model is dynamic, due to the related processes with other organizational systems in order to optimize operations.

An existing business process can be innovated (Business Process Improvement), or fundamentally improved (Business Process Reenginering).

To create the project, the standards for functional modeling IDEF0, realized through the BPwin CASE tool, were also used. (IDEF0 Standard, www.idef.com).The IDEF0 is a modeling technique based on a combination of graphics and text presented in an organized and systematic manner in order to increase user-friendliness and provide logic for potential changes and specified requirements, ie. to support the analysis of the system according to the levels (Veljović, 2002).

The activity tree shown in Figure 3 represents a strategic decision of the company management and is not an organizational chart. To abandon the "organizational" approach and adopt the process approach, it is necessary to imagine that only one person performs all tasks in the organization.

Jobs at the top (root) are always marked with 0 . The numbers are used to show how much detail a job contains. Business $A 0$ is decomposed (separated) to 1, 2, 3, etc. Job 1 is composed of 11, 12, 13, 
etc. A higher-level job is called a "parent", and subordinate jobs are "children".

The activity decomposition of parents to their children should have 3 to 6 subordinate activities. More than six out of a certain activity is an attempt to fit too much detail into one level.

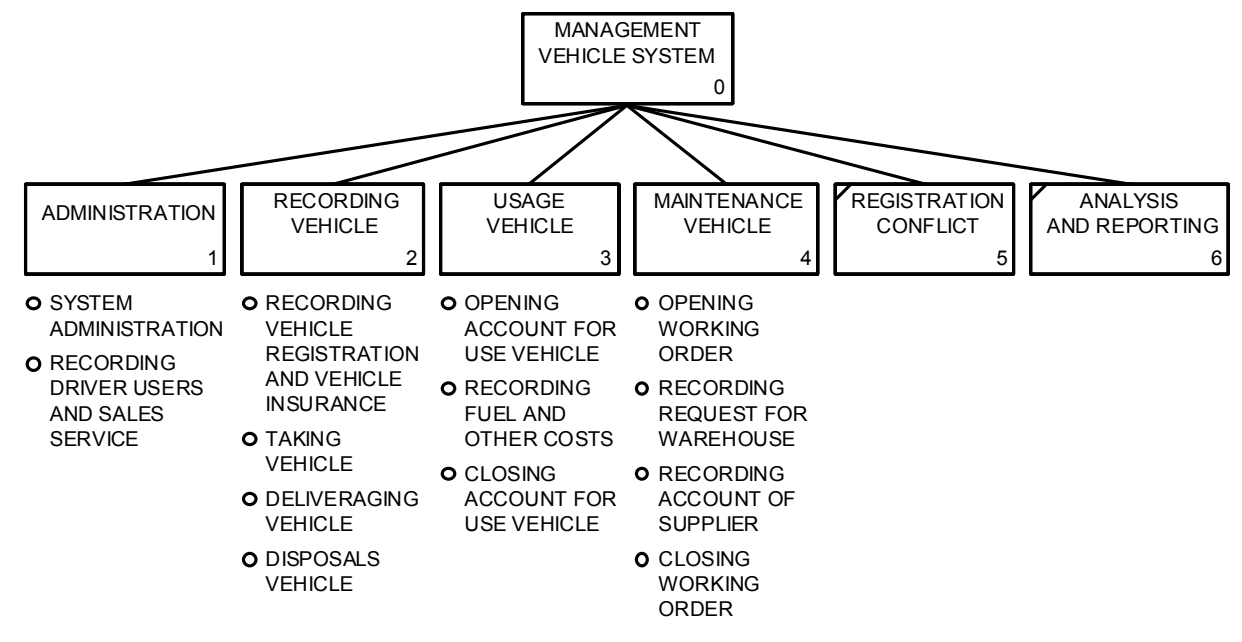

Figure 3 - Activity tree

Puc. 3 - Ветви деятельности

Slika 3 - Stablo poslova

This approach makes it easy to connect with the future development of an integrated IS and it meets the requirements of ISO 9000 quality management system.

In the phase of the system functional decomposition, there were used decomposition diagrams that show the place / position of abusiness process in the organizational structure of the organization, as well as guidance and examples for the design of business processes and systems for a vehicle management system(van der Aalst, 2013).

The decomposition of functional domains and a complex process of <<Business Domain >> to primitive process stereotype <<b Process UC>> is described in the paper (Terzić, 2015). In this paper, theprocess area vehicle management systemis presented in Figure 4. 


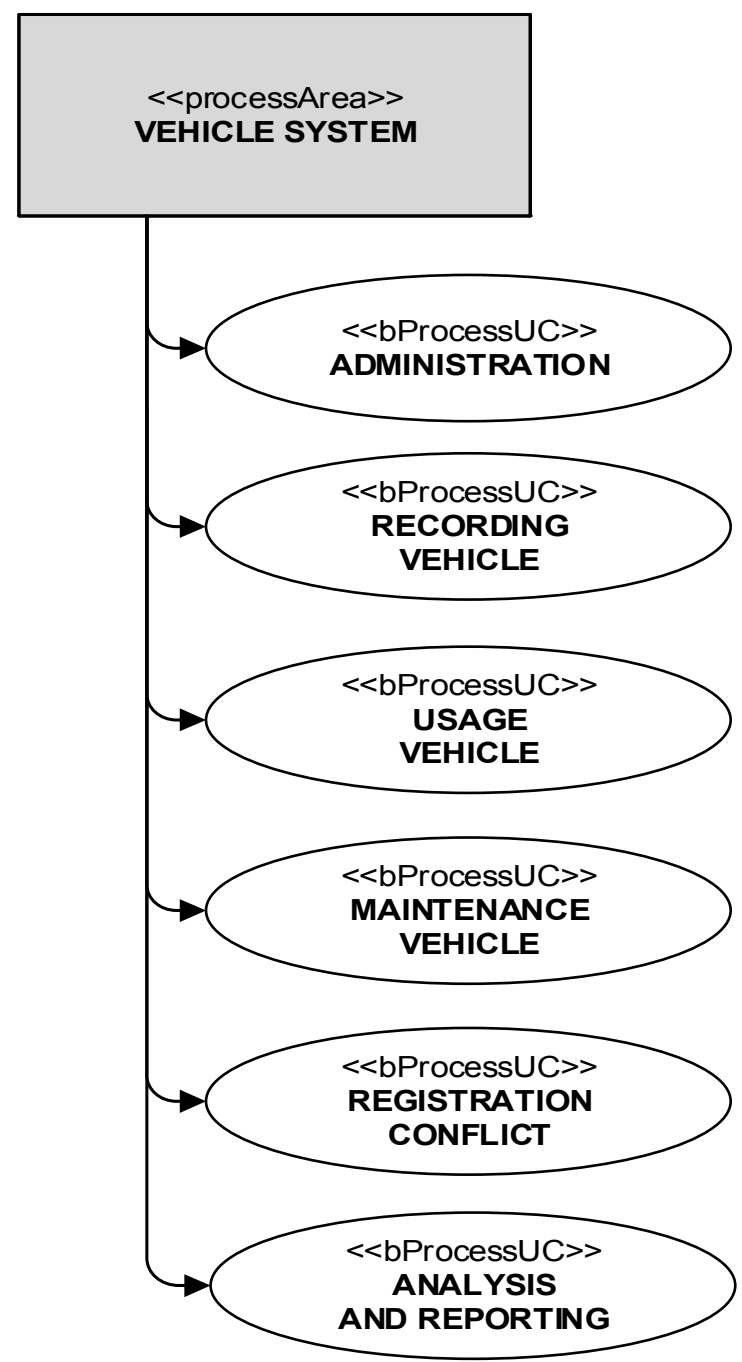

Figure 4 - Process Area - company vehicle

Puc. 4 - Процессная область - служебный автомобиль

Slika 4 - Procesno područje - službeno vozilo

A primitive business process can be performed using the Unified Modeling Language (UML) diagram of a use case to define the specification of interactions between the system actors (participants), together with a description of actions in this system interaction. The Use Case diagram is shown in Figure 5. 


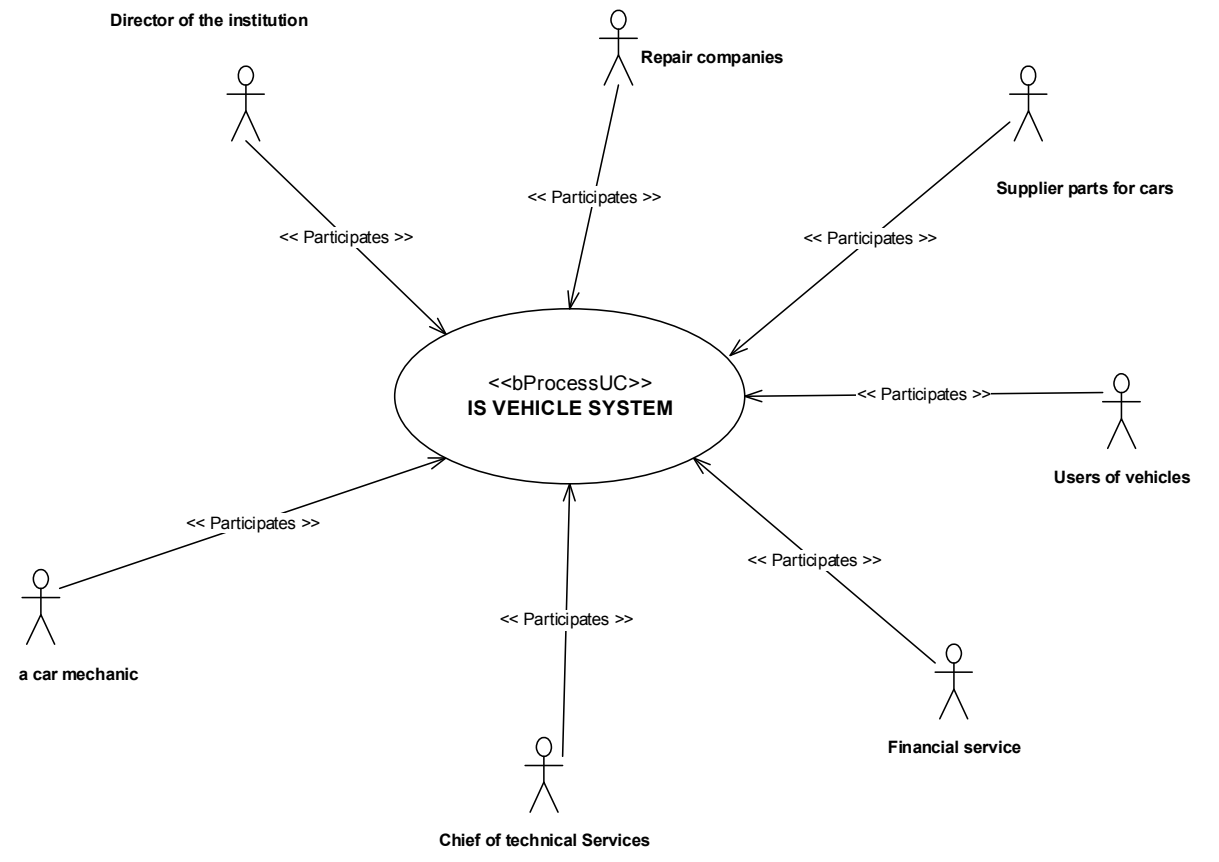

Figure 5 - Use Case Diagram

Puc. 5 - Диаграмма прецедентов

Slika 5 - Dijagram slučaja korišćenja

The Use Case diagram (Figure 5 ) shows the business process and all the actors / participants in the business process VP.

After performing the functional decomposition of the system and the global description of the primitive process through the model use cases, it is necessary to identify business processes precisely, in detail and possibly to formalize the min order to allow the automation and execution of the system for business process management.

Specifications of business processes are implemented into BPMN (Business Process Model and Notation) diagrams.

A graphic-oriented language was used here for modeling business processes BPMN 2.0 (Allweyer, 2010) and (OMG 2010) and (OMG 2011).

Version 2.0 BPMN modeling language business process has a very rich set of concepts and provides several different types of diagrams for expressions of choreography and orchestration at different levels of abstraction.

BPMN has "elementary and complex concepts for modeling business processes". BPMN elementary concepts can be classified into one of the following five basic categories (Nešković, Petrović, 2009) Flow Objects, Connection Objects, Swim Lanes, Data Objects, and Artifacts. From these elementary concepts, complex concepts can be built: Orchestration, Collaboration, Choreography and Conversation. 


\section{BPMN diagramming of the ride order management process}

For the purpose of this article, the business process management of a ride order is described in detail.

A flowchart / Collaboration (Figure 6) is used to display orchestration because the dates of BPMN 2.0 process orchestration means the activities it is composed of. This type of standard diagrams contains the flow of objects (activities, events and dates) that are associated with the flow of sequences. Collaboration describes the interaction between two or more business entities. It usually contains two or more partitions (pools).

Actors / participants in this context are the user of the vehicle, an administrative worker, the Head of the Vehicles System, a car mechanic and a central warehouse operator.

The ride order business management process starts when a customer comes into the Vehicle Technical Service with a request to use a vehicle. The vehicle user first makes a request to use a vehicle. After checking the roadworthiness of vehicles and their availability, the process continues.

An administrative worker records the received request and forwards the request to the Head of the Vehicles System. Depending on the technical validity / availability of the vehicles system, the Head approves or refuses the vehicle use.

In the event that a technical defect on the vehicle is detected, or that a vehicle has already been in the process of defect detection, parts are required from the central storage and the fault is repaired. Upon completion of this process, the Head of the Vehicles System or the Head of the Technical Service is informed that the vehicle is repaired and ready for use.

In the event that the request for the use of vehicles is refused, the user is notified about it.

If the request for the vehicle use is approved, a ride order is created and the further use of the vehicle is monitored.

During the use of company vehicles, fuel costs and repair costs can occur due to malfunction or damage to the vehicle. In both cases, upon returning to the organization, the bills of incurred costs during the use are submitted.

At the end of the process of using a company vehicle, the vehicle is parked in a parking lot, the keys are handed over, the ride order for that particular passenger vehicle is completed as well as any proofs of costs if they have occurred during the use of the vehicle and the vehicle parking place is recorded.

The last stage in the process of managing a ride order is to update the database and change the status of the vehicle at leisure for the next usage. 


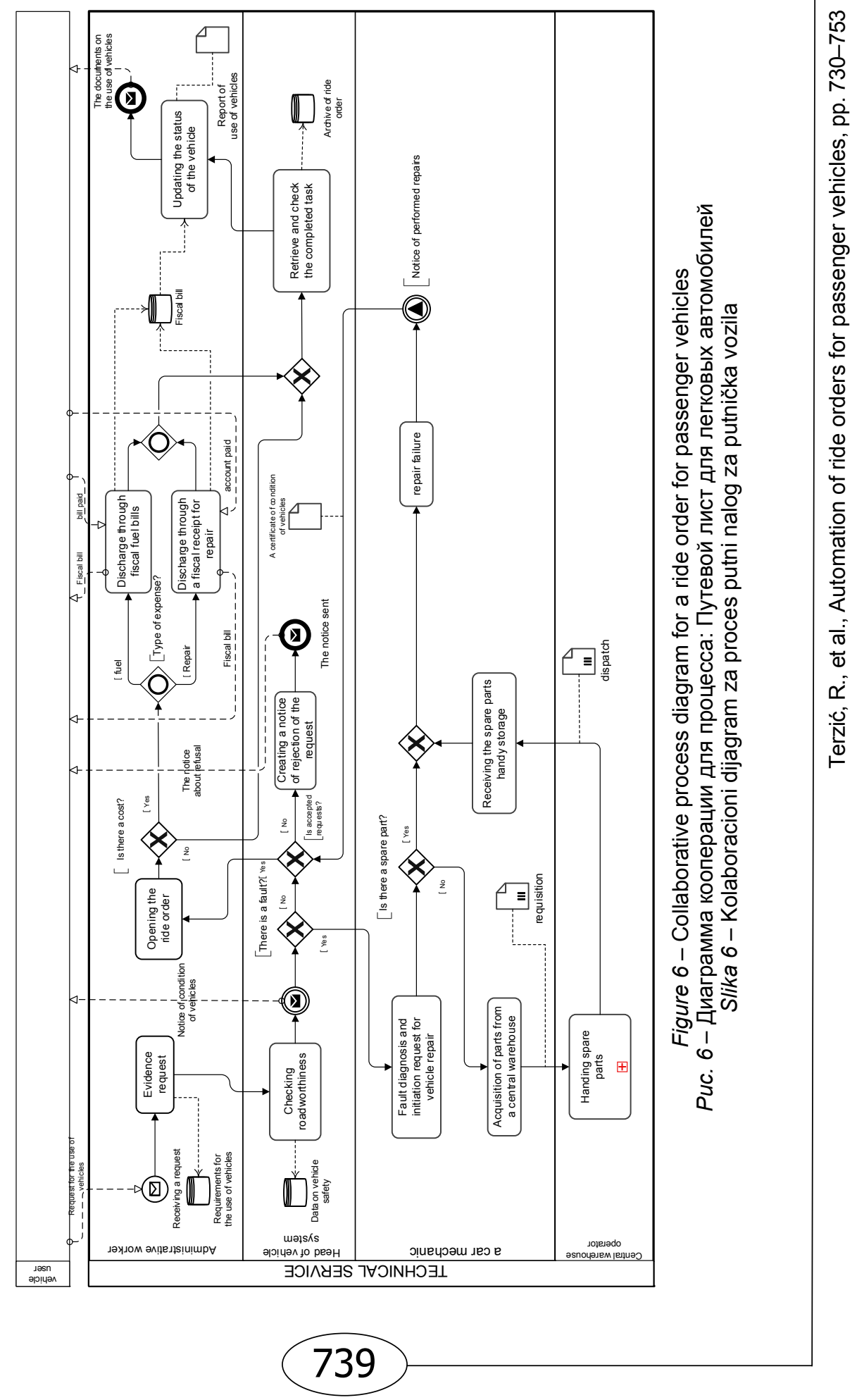


Choreography (Figure 7) observes the process through a set of messages exchanged between the participants. It defines the expected behavior among participants. Unlike internal processes that exist within a single partition (pool), choreography exists between partitions (pools) and participants. We will define the sequence of messages which are exchanged.

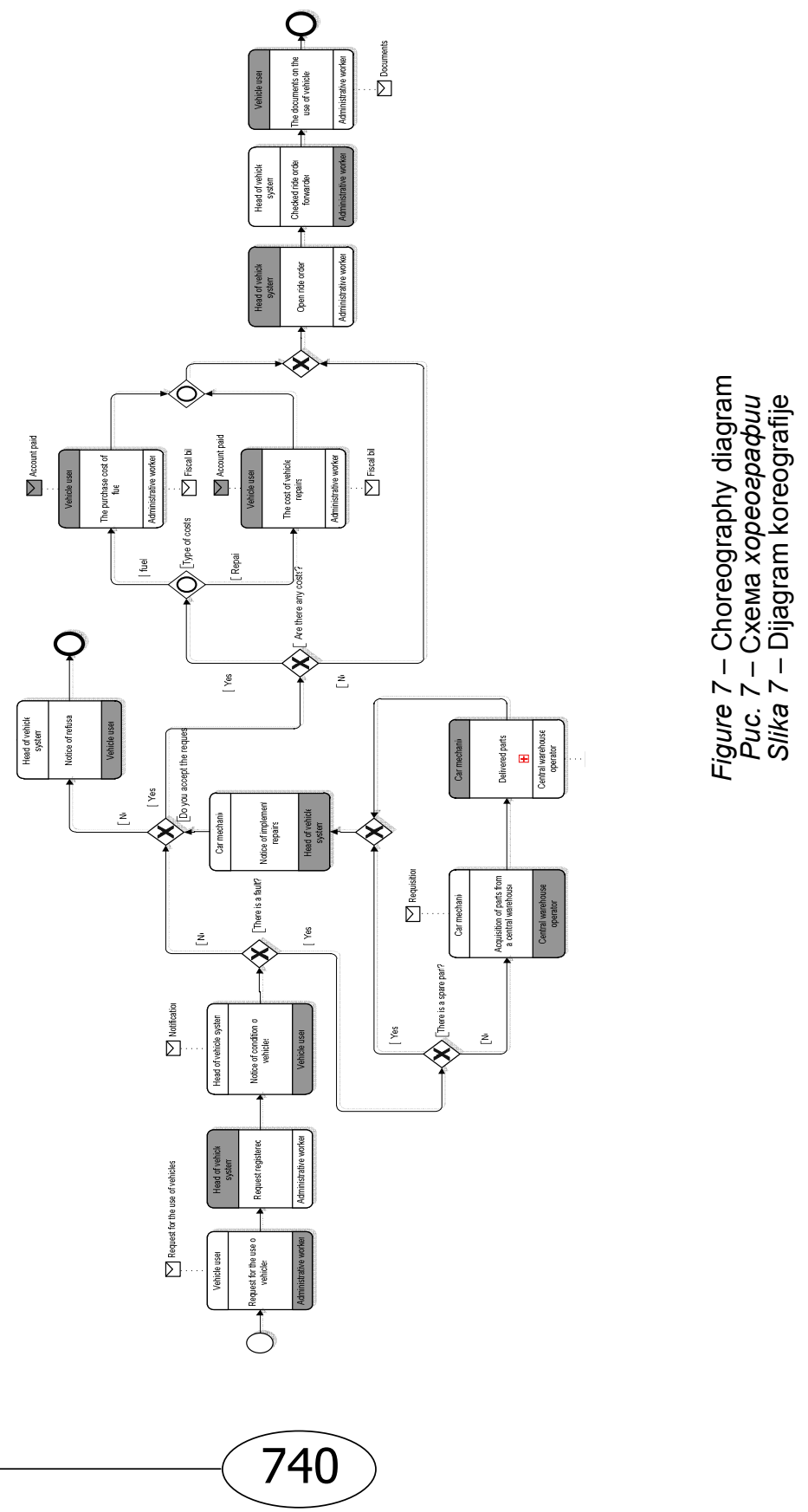


The first message in this process is a request for the use of the vehicle. That request is forwarded to the chief administrative officer (the Head) of the Vehicles System. On the basis of the vehicle operational state and availability check, the subsequent messages are generated.

If the vehicle has a defect, an order for the fault removal is written. Upon the failure detection, if a spare part for the vehicle repair is needed, a mechanic fills in an order for a requisition / purchase of the particular spare part(s).

When purchasing the required spare part, the operator dispatches the required part through the central warehouse. After the vehicle repair, a car mechanic sends a certificate of roadworthiness for the vehicle.

Defect-free vehicles are taken on the basis of an open ride order.

During the use of company vehicles, additional costs may occur. These are the costs for repairs of unplanned failures and the costs for filling up the tank.

Upon completion of the use of the vehicle, the handover is completed with the bills of costs incurred during the use of the vehicle as well as the vehicle keys.

If you do not approve the use of the vehicle, the vehicle user receives a negative response.

\section{Design results}

The VozIS information system is used for recording data on the use of vehicles, recorded registration processes, servicing, ride orders for passenger vehicles, costs related to vehicle fuel consumption and system created / produced documents - reports based on ISO standards (e.g. Receipt form).

Data is entered when necessary. All the required information on individual vehicles can be recorded in a very simple and clear way.

The program itself informs the user when it is time for the registration service, the predefined number of days or the number of kilometers in advance. It is possible to record an unlimited number of vehicles, vehicle data, periodic maintenance, driving and vehicle operating costs. The program includes a full set of supporting records in which the data is sufficient to be defined only once, and then any number of times entered in the register simply by selecting from the drop-down list. Therefore, entering data into the program is simplified and fast, while a manual entry of the same data is completely eliminated. 
At any time, entered data can be viewed, changed, print or sent by e-mail. The program generates a lot of useful reports and is suitable for the planning of future expenditure and a number of reports such as:

-View all costs within a certain time interval for all or a specific vehicle. This refers to services, registration, fuel and other costs.

- Only the cost price per day for one or more vehicles.

- Only the cost per driver or all the drivers.

- Control and supervision of the finance concerning fuel, maintenance and other costs, average fuel consumption by one or more vehicles.

- The information required to create long-term and short-term work plans in this business segment,

- More efficient business management system, analyzing and processing reports,

- No data redundancy,

- Eliminate unclear, incomplete, undefined requirements and overcome the problem of technological backwardness at work,

- The quality of operations is better as well as the mutual coordination of all users of company vehicles.

- Implemented reports in the IS should provide relevant information on the state of the observed business system, and will be the basis for faster management and a more efficient decision-making and management system.

\section{The implementation process, its execution and automation}

Defining the shape and appearance was realized in Access, while the external data sources were stored in the SQL server database.

The on-screen forms that represent the results of modeling business processes are shown further on.

After a successful login to the app, the home screen shows all the programmed functions. The content is visible: the system (part of the entire management information system), administration (management of all application objects), business partners (recorded by all business partners and persons in the application), lists of values (here is the skeleton system updated), registration of vehicles (entry on organization vehicles), the use of vehicles (recorded use of the vehicle), vehicle maintenance (these entries show routine servicing and repair), reports (starting programmed reports for work analysis), Description (part of the application), search (fast access to different information in this system). 


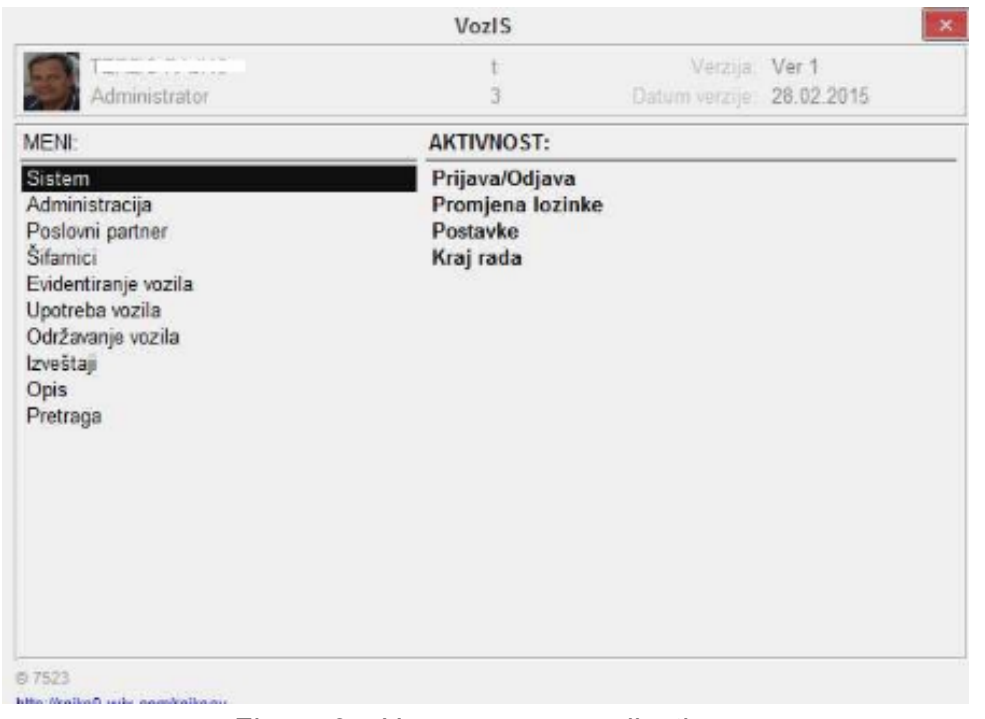

Figure 8 - Home screen applications

Puc. 8 - Главный экран приложения

Slika 8 - Početni ekran aplikacije

Form programmed to be displayed on the screen: Record of the vehicle technical data

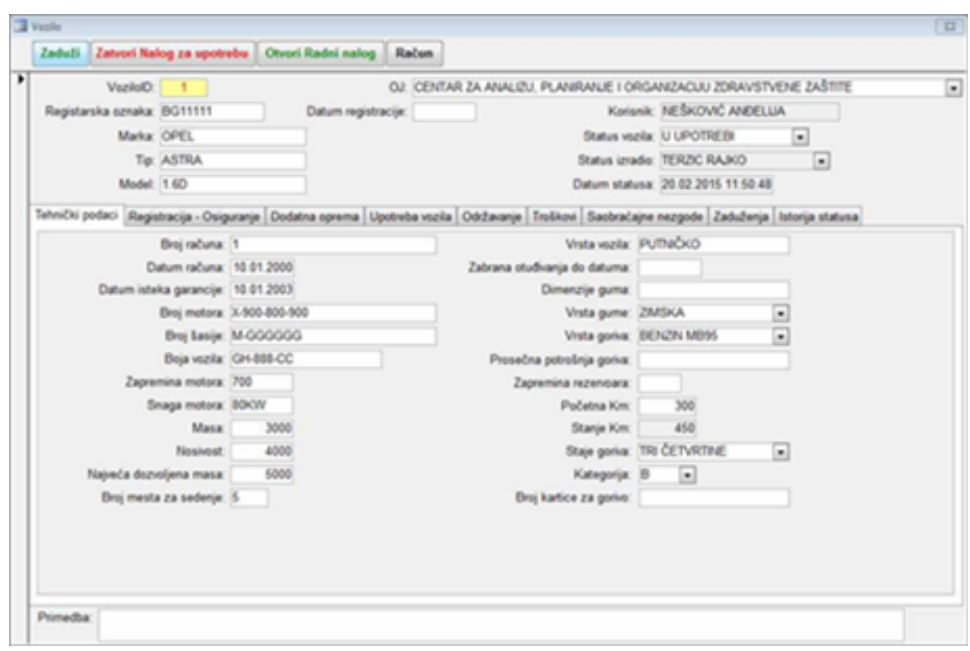

Figure 9 - Entering the technical data of the vehicle

Puc. 9 - Учет технических данных транспортного средства Slika 9 - Unos tehničkih podataka o vozilu

The most important technical data for each company vehicle used in the organization is entered into this programmed form. 


\section{Form programmed to be displayed on the screen: Vehicle registration}

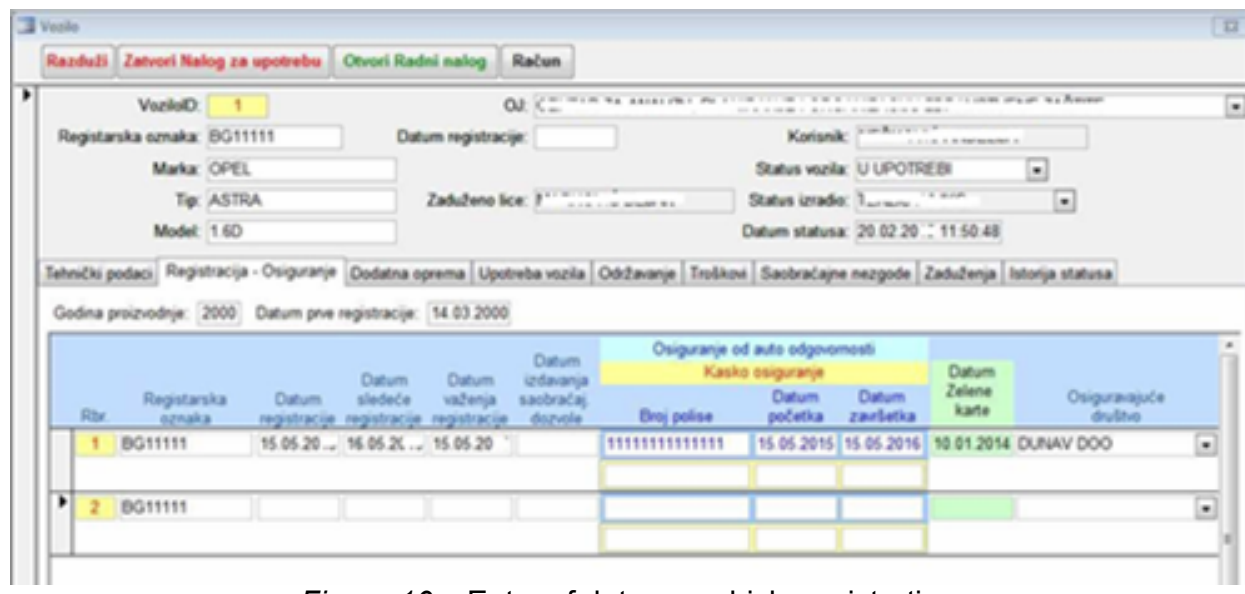

Figure 10 - Entry of data on vehicle registration

Puc. 10 - Учет данных о регистрации транспортного средства

Slika 10 - Unos podataka o registraciji vozila

Data relevant to the process of renewing the registration of vehicles is entered into this form.

Form programmed to be displayed on the screen: Entry of accessories

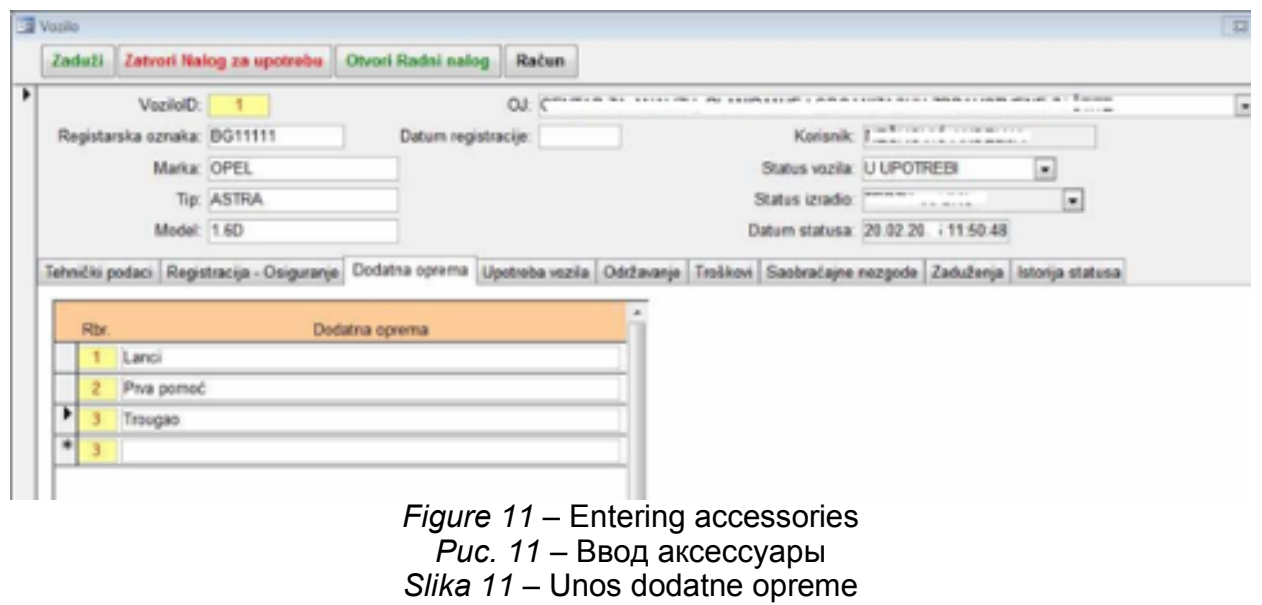

Data on accessories which go along with the borrowed vehicle is entered into this programmed form. 
Form programmed to be displayed on the screen: Use of the vehicle

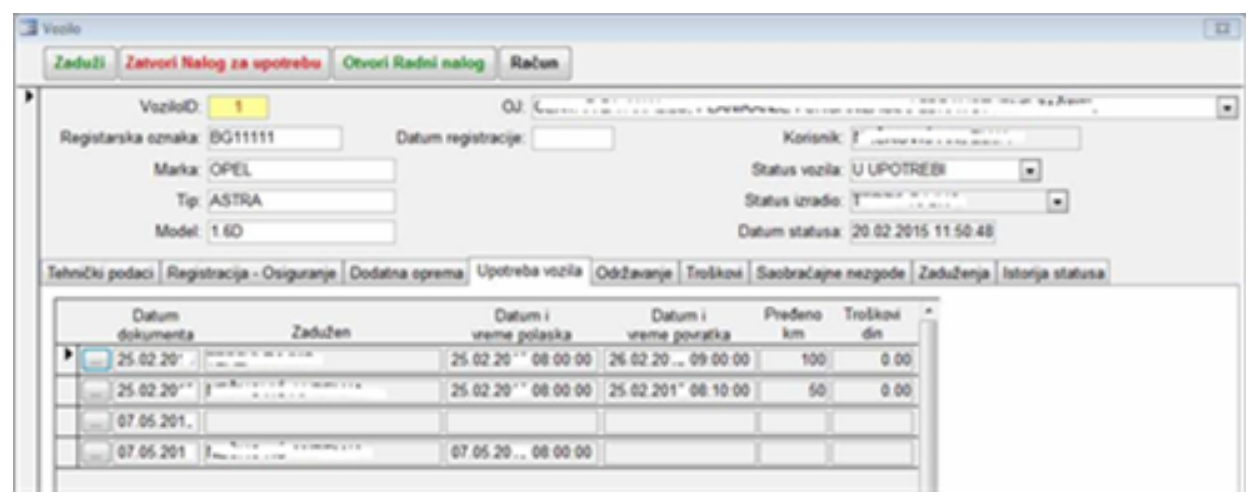

Figure 12 - Overview of the vehicle use

Puc. 12 - Сводный отчет по транспорту

Slika 12 - Pregled upotrebe vozila

This display form can quickly show the data on the use of vehicles, the mileage and expenses incurred during the use of vehicles.

Form programmed to be displayed on the screen: Costs during the use of the vehicle

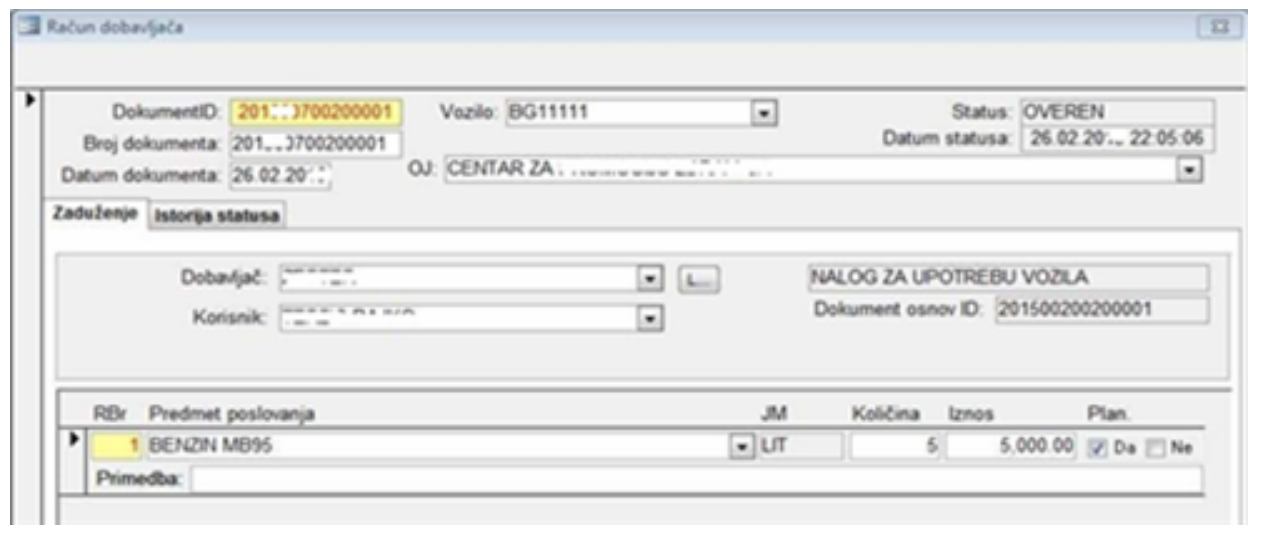

Figure 13 - Input of costs during the vehicle use

Puc. 13 - Накладные расходы во время использования транспортного средства Slika 13 - Unos troškova tokom upotrebe vozila

Costs for each vehicle in the fleet are entered into this form. 


\section{Form programmed to be displayed on the screen: Costs}

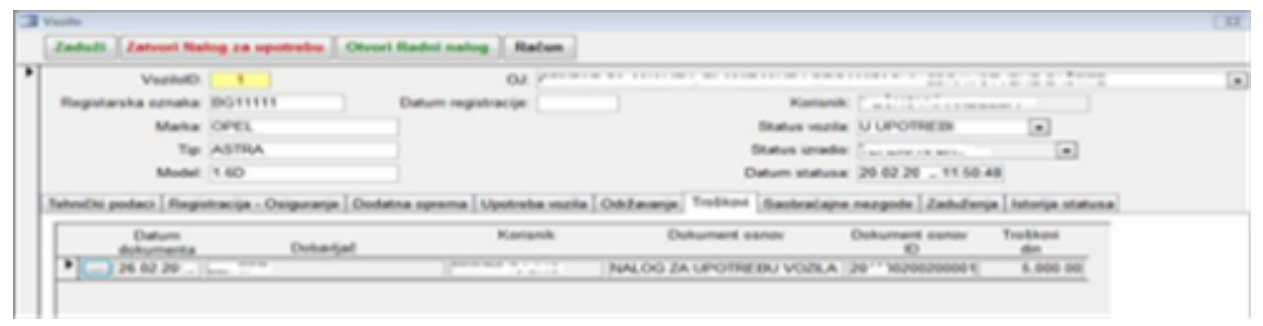

Figure 14 - Overview of costs for a selected vehicle

Puc. 14 - Обзор расходов по выбранному транспортному средству Slika 14 - Pregled troškova za izabrano vozilo

This form shows a summary for each document created during the vehicle usage. There are dates and suppliers for each document as well as a total amount of costs.

\section{Form programmed to be displayed on the screen: Allocating vehicles}

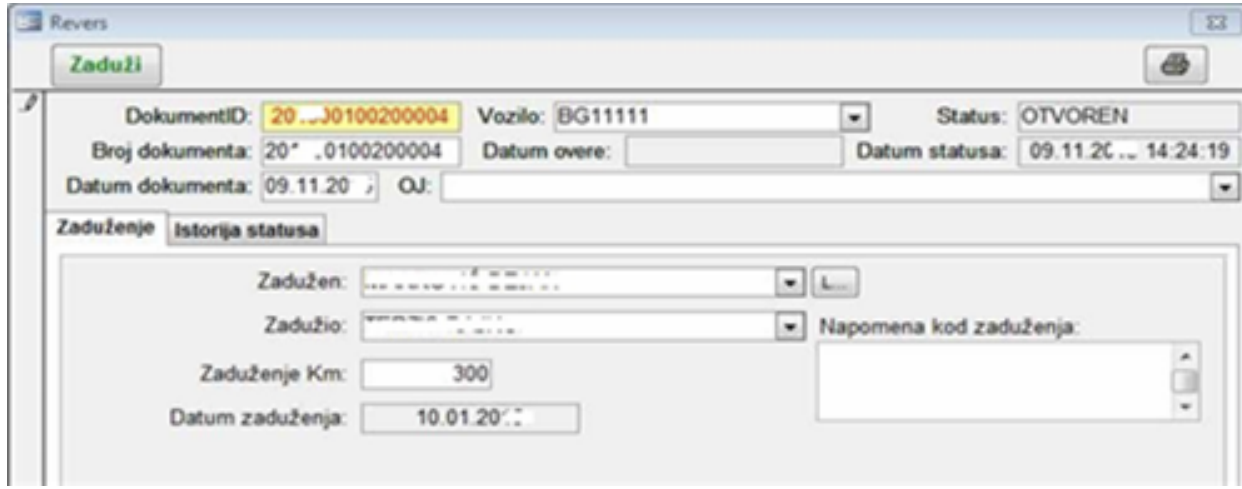

Figure 15 - Procedure of allocating vehicles

Puc. 15 - Процедура оформления транспортного средства Slika 15 - Procedura zaduženja vozila

Vehicle allocation data is shown in this form: the name of the person the vehicle is allocated to, how many kilometers the vehicle has ordered in time duties, the time and any notes on the condition of the vehicle at the time of borrowing. 
Form programmed to be displayed on the screen: Overview of the liabilities for vehicles

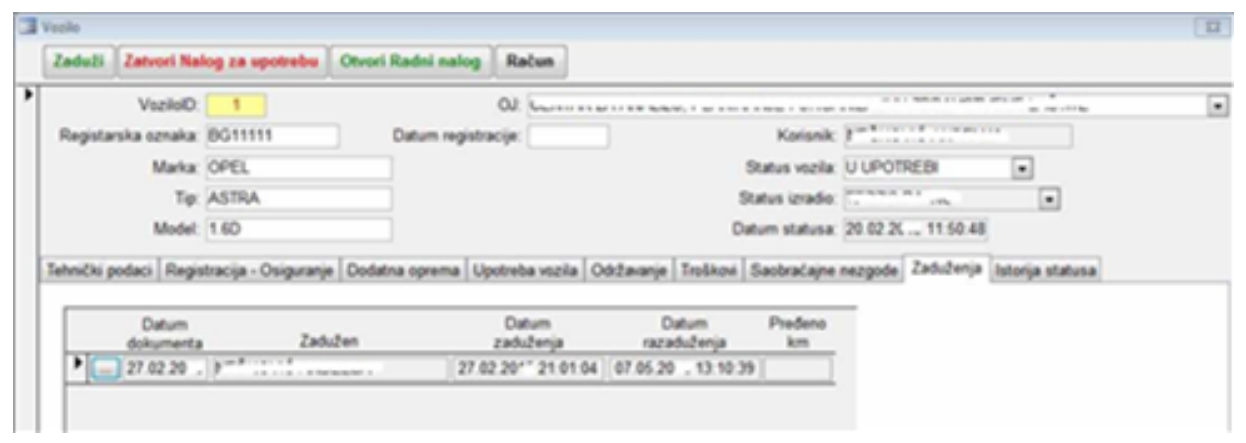

Figure 16 - Procedure of allocating vehicles

Puc. 16 - Процедура оформления транспортного средства

Slika 16 - Procedura zaduženja vozila

This form shows the listing tasks and the use of each vehicle.

Each vehicle in the organizationis allocated with a receipt and the liability for each vehicle is determined. This screen contains the history of the vehicle usage.

Form programmed to be displayed on the screen: Return of the vehicle

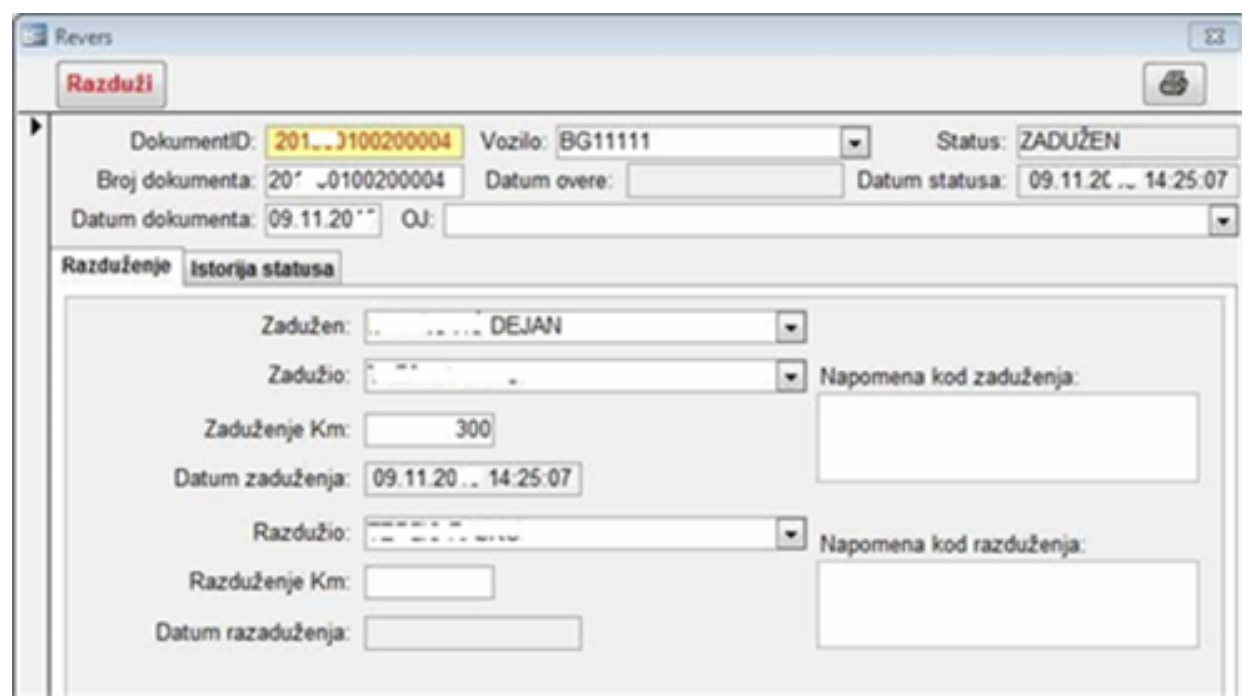

Figure 17 - Paperwork procedure for officially returning vehicles

Puc. 17 - Процедура закрытия путевых листов

Slika 17 - Postupak razduženja vozila 
After a period of vehicle use, a person liable for the vehicle is to return it. At that point, the following data is entered: date of the official return of the vehicle, the person who returned the vehicle, the mileage on the date of return, as well as the description of the condition of the vehicle at the time of return.

Form programmed to be displayed on the screen: Vehicle ride order

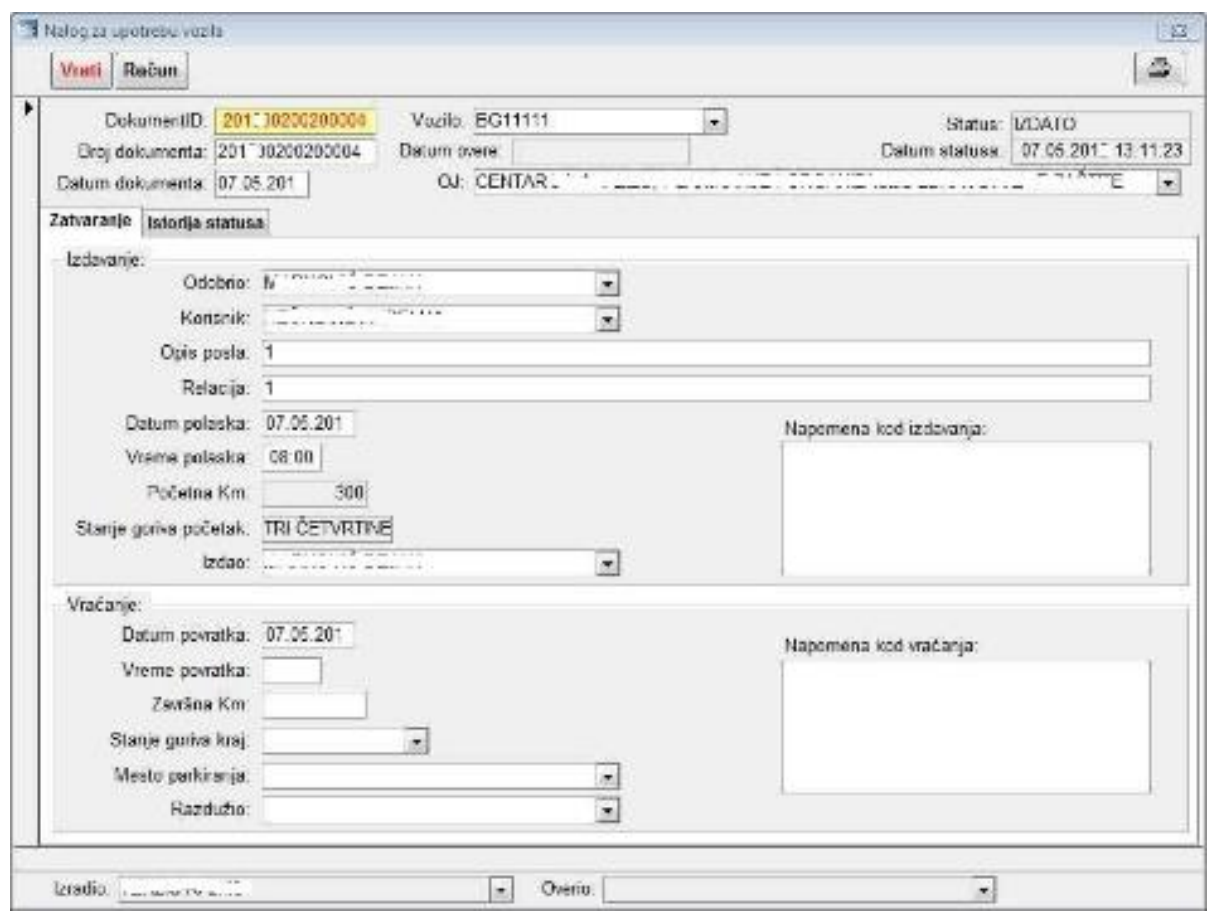

Figure 18 - Procedure of opening a vehicle ride order

Puc. 18 - Порядок выписки путевого листана транспортное средство Slika 18 - Procedura otvaranja naloga za upotrebu vozila

When the use of a company vehicle has been approved, a ride order for a passenger vehicle is opened. The entries are: ground vehicle use the purpose for using the vehicle and the distance, the date and the time of taking over the vehicle, the initial state of the odometer, fuel level in the tank and the person who approved the use of the vehicle.

Upon completion of the vehicle usage, the date and the time of return of the vehicle are recorded. In addition, the final entries are the mileage, fuel level upon return, a place to park and the person who took the car keys. 


\section{Output document: \\ Printed ride orders for passenger vehicles}

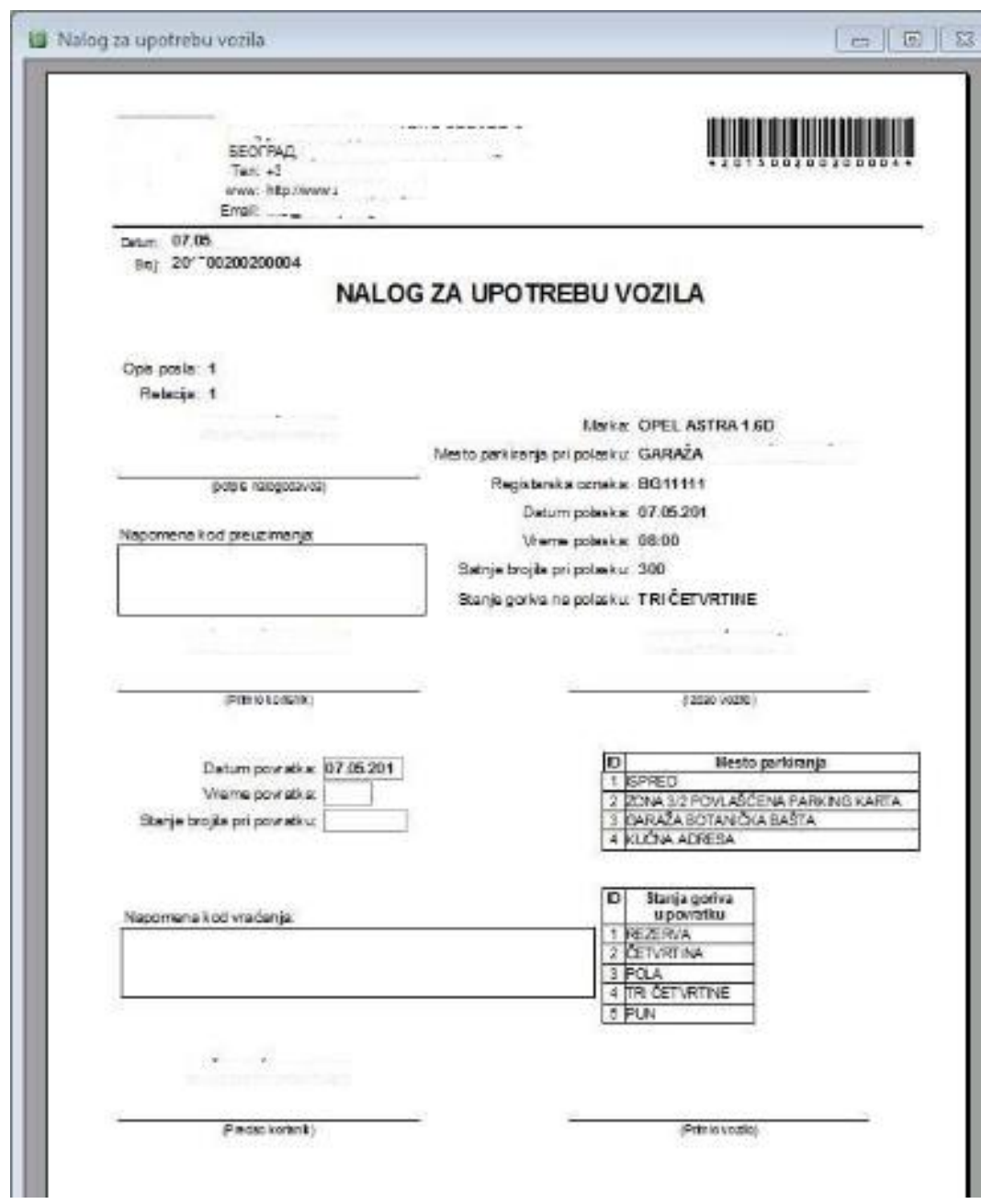

Figure 19 - Procedure of handing in a vehicle ride order Puc. 19 - Порядок оформления заявки на использование транспортного средства Slika 19 - Procedura predaje naloga za upotrebu vozila

At the beginning of the process, the employee receives initially filled ride order. Upon completion of the use of the vehicle, the employee returns the completed ride order for passenger vehicles with the data on kilometers ordered, a place to park the vehicle and the date and the time of the vehicle delivery. 


\section{Conclusion}

Completely new directions in the organization of business processes are being created and of particular importance is the development of a system for managing business processes, based on explicitly designed processes and providing support in the execution and management of operational business processes.

An important requirement is knowledge of business processes. The main contribution of this paper is defining the approach for modeling and implementing business processes through a selection of tried and tested methods and models for dealing with the complexities of system selection and implementation of executive decisions.

This paper presents an approach for modeling business processes through a choice of methods and models for coping with the complexity of the system (Mayer, et al., 1995). The application of the proposed methods and models is illustrated through the decomposition of business processes and a detailed specification of the business process in creating ride orders for passenger vehicles.

The presented example of defining the process model of a ride order for passenger vehicles is a way to simultaneously describe the dynamics of information for the IS development. Using contemporary design and the use of CASE tools can be extended and modified, because all changes are easily installed. The presented methodology for the design of information systems and CASE tools can be used for any system or phenomenon studied and implemented on a computer (Lazarevic et al., 2006).

Precisely and formally defined business process models were the basis for configuring the IS, but will be used for the analysis, understanding and continuous improvement of the process they describe. It is important to identify and describe all the processes; otherwise, the system will be incomplete. Being living organisms, business processes are not standardized, but they can be optimized.

Establishing business process management is not only an aspect of understanding the flow of operations and other elements of organizational design. Other dimensions of establishing business processes are accurate implementation of functionality to the design of business processes, business process improvement and alignment with the solution of this improvement, management of changes in the design process that arise during the implementation of solutions, the introduction of end-users to work and training about specific functionalities related to administration for a process in which they are protagonists.

This paper presents a combination of theory and practice as theoretical aspects are exposed to real results. The paper shows the implementation processes, their implementation and their automation. 
The executive specification of the program is realized on the Access / SQL Server platform.

The appearance of screen forms was implemented on the MS Access platform, while the external data sources were stored in the SQL server database.

The automated solution increases the quality of operations and coordinates all the participants in this business system.

The ultimate goal is the development of an IS which will be based on business processes, i.e.in which business processes will be first-order entities. Precisely and formally defined business process models will be the basis for configuring the IS, but will also be used for the analysis, understanding and continuous improvement of the process they describe (Terzić, et al., 2014). This IS concept will be able to continuously offer an adequate support to business systems and it will enable successful achievement of business objectives of organizations.

\section{References}

Allweyer, T. 2010. BPMN 2.0 Introduction to the Standard for Business Process Modeling. Norderstedt: Herstellung und Verlag: Books on Demand $\mathrm{GmbH}$.

Aničin, M., \&Pantović, V. 2014. Sinergija više domenskih znanja, kao kritičan faktor uspeha kompleksnih projekata. U: Infotech Ict conference \& exhibition, Aranđelovac. Aranđelovac.

Harrington's, J. 1991. Business Process Improvement.

IDEFO Standard. Preuzeto sa www.idef.com.

Lazarević, B., Marjanović, Z., Aničić, N., \& Babarogić, S. 2006. Baze podataka. Beograd.

Mayer, R., Menzel, C., Painter, M., Perakath, B., de Witte, P., \& Blinn, T. 1995. Information Integration for Concurrent Engineering (IICE) - IDEF3 Process Description Capture Method Report. Technical Report, September.

Nešković, S., \& Petrović, M. 2009. Modelovanje poslovnih procesa korišćenjem OMG BPMN 2.0standarda. InfoM, 31.

OMG. 2010. Unified Modeling Language (UML) Specification ver. 2.4 Super structure. OMG Document ptc/-11-14.

OMG. 2011. "Business Process Model and Notation (BPMN)", Version 2.0. Preuzeto sa http://www.omg.org/spec/BPMN/2.0

Terzić, R., Majstorović, M., \& Terzić, D. 2014. U pravcu upravljanja poslovnim procesima u sistemu za imunizaciju pacijenata. U: Infotech ict conference \& exhibition, Aranđelovac. Aranđelovac.

Terzić, R. 2015. Modelovanje poslovnih procesa za upravljanje voznim parkom. U: Infotech ict conference \& exhibition, Aranđelovac. Aranđelovac.

Tumbas, P. 2006. Upravljanje poslovnim procesima. Preuzeto sa http://www.ef.uns.ac.rs/obavestenja/doktorske/upravljanje-poslovnimprocesima/2013-03-12-UpravljanjePP-01-2013.pdf 2006 Jan 12.

UN/CEFACT. Modeling Methodology (UMM) User Guide CEFACT/TMG/N093 V20030922. 
Van der Aalst, W. 2013. Business Process Management: A Comprehensive Survey. ISRN Software Engineering.

Veljović, A. 2002. Modeliranje informacionih sistema. Beograd: Megatrend univerzitet primenjenih nauka.

Weske, M. 2007. Business Process Management: Concepts, Languages, Architectures. Berlin: Springer-Verlag.

\section{АВТОМАТИЗАЦИЯ ВЫПИСКИ ПУТЕВЫХ ЛИСТОВ НА ЛЕГКОВЫХ АВТОМОБИЛЕЙ}

Райко М. Терзич ${ }^{\mathrm{a}}$, Зоран С. Эремияб

а Городской институт общественного здравоохранения, г. Белград,

Республика Сербия,

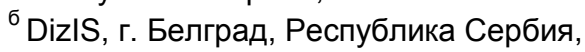

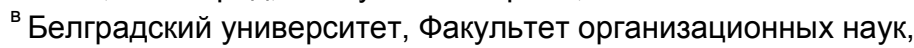
Республика Сербия

ОБЛАСТЬ: компьютерные науки, информационные технологии, промышленное программное обеспечение

ВИД СТАТЬИ: оригинальная научная статья

ЯЗЫК СТАТЬИ: английский

\section{Резюме:}

Эфрорективная деятельность организации зависит от качества управления взаимосвязанными и бизнес-процессами. Инфрормационная система VozIS разработана с целью обеспечения ввода данных, в тех областях, где это необходимо.

Благодаря автоматизированному учету данных о служебных автомобилях их использовании и сервисе (в т.ч. о регистрации, страховании, ремонте, путевых листах, накладных расходах и пр.) созданы реальные условия для эфффективного управления деловой системы, контроля фринансовых средств, долгосрочного и краткосрочного планирования деятельности, а также для оформления отчетов.

Cucmeмa VozlS исключает все нечеткости, неполные заявки и ускоряет технологический процесс работы. Автоматизация повышает качество делопроизводства, координируя всеми участниками деловой системы. $B$ статье ставится акцент на применяемые методы бизнес-анализа и приведены результаты проектирования в области разнарядки путевых листов легковых автомобилей и деловых процессов, связанных с данной областью.

Ключевые слова: служебный автомобиль, путевой лист, транспортное средство, BPMN, UML, BPM, системы управления бизнес-процессами, бизнес-процесс. 
Paper received on / Дата получения работы / Datum prijema članka: 11. 02. 2016. Manuscript corrections submitted on / Дата получения исправленной версии работы / Datum dostavljanja ispravki rukopisa: 19. 04. 2016.

Paper accepted for publishing on / Дата окончательного согласования работы / Datum konačnog prihvatanja članka za objavljivanje: 21. 04. 2016.

(C) 2016 The Authors. Published by Vojnotehnički glasnik / Military Technical Courier (www.vtg.mod.gov.rs, втг.мо.упр.срб). This article is an open access article distributed under the terms and conditions of the Creative Commons Attribution license (http://creativecommons.org/licenses/by/3.0/rs/).

(C) 2016 Авторы. Опубликовано в "Военно-техническийвестник / Vojnotehničkiglasnik / Military Technical Courier" (www.vtg.mod.gov.rs, втг.мо.упр.срб). Данная статья в открытом доступе и распространяется в соответствии с лицензией "CreativeCommons" (http://creativecommons.org/licenses/by/3.0/rs/).

(C) 2016 Autori. Objavio Vojnotehnički glasnik / Military Technical Courier (www.vtg.mod.gov.rs, втг.мо.упр.срб). Ovo je članak otvorenog pristupa i distribuira se u skladu sa Creative Commons licencom (http://creativecommons.org/licenses/by/3.0/rs/).

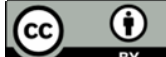

